Copyright (C) 2021 by Cherkas Global University

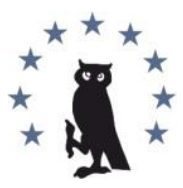

Published in the USA

Media Education (Mediaobrazovanie)

Has been issued since 2005

ISSN 1994-4160

E-ISSN 2729-8132

2021. 17(4): 601-611

DOI: $10.13187 / \mathrm{me} .2021 .4 .601$

https://me.cherkasgu.press

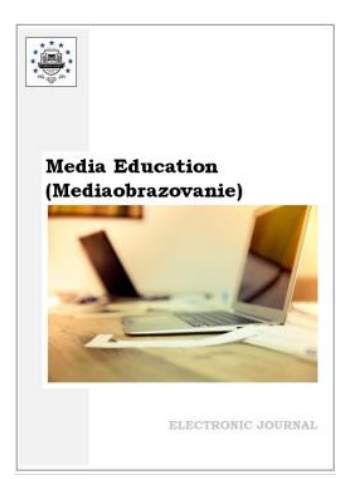

\title{
Teaching Methods for Modeling the Image of Territory in a Media Text: The Problem of Meaning Formation
}

\author{
Irina Erofeeva ${ }^{a},{ }^{*}$, Galina Melnik ${ }^{b}$, Natalya Prostokishina ${ }^{c}$ \\ a Transbaikal State University, Russian Federation \\ b Saint Petersburg State University, Russian Federation \\ c State Television and Radio Broadcasting Company-Chita - a branch of the All-Russian State \\ Television and Radio Broadcasting Company, Russian Federation
}

\begin{abstract}
The purpose of the article is to summarize the methodological experience of work on the value-semantic component of modeling the media image of territory in the process of creating a media text of different genres and designs, to characterize the pedagogical technologies of teaching text construction using conceptual representations of society, its cultural memory.

The article presents the characteristics of methodological materials on the formation of the competence of the media text author working with the territory's media image used in the ours of training "Journalism", "Advertising and Public Relations" - the bachelor's degree, the master's degree. Cognitive means of a media text addressed to the sociocode of culture have been highlighted. Using them, the textured material is percepted and processed in modeling the media image of a country or a region. Active and interactive teaching methods focused on reflection and conscious use of these tools in the media text author's creative activity have been structured. The authors propose several tasks for active, problem-based learning and articulate the culturological model of education in forming professional competencies in modeling a media image, which replenishes the educational environment with sociocultural meanings characteristic of a person's territory.

Keywords: value-semantic component of modeling the media image of the territory, teaching methods, cultural memory, national picture of the world, conceptual modeling, media culture.

\section{Introduction}

The study is relevant due to the significant role of modern media in shaping the image of a specific territory in the mass consciousness, on which economic, political and social relations in society directly depend. Nevertheless, there are clearly not enough methodological materials on this issue; there are basically no studies on specific work with the media image within the framework of the media text.

The authors of the article were guided by the desire to summarize the methodological experience of work on the value-semantic component of modeling the media image of territory in the process of creating a media text of different genres and designs; to analyze active teaching methods for modeling a productive media image of territory based on mental representations and semantic frameworks of the society's worldview; to generalize the pedagogical technologies of higher education, which make it possible to train future mass communication workers to deal with

\footnotetext{
* Corresponding author

E-mail addresses: irina-jour@yandex.ru (I. Erofeeva)
} 
cognitive strategies that take origins in culture and guarantee effective interaction with the target audience, with its value preferences and behavior patterns.

\section{Materials and methods}

The study uses many interdisciplinary methods: the systematic and pragmatist communicative method and the axiological approach are focused on the use of scientific material in the classroom as a means of effective socialization and interpersonal, as well as mass communication of future professionals. The process of classroom and independent work with these established mental representations of Russia is focused on students discovering the correlation of primordial meanings and their transformation in the mass media discourse. A survey of active journalists from different communication channels made it possible to identify the study's relevance and the need for pedagogical work aimed at mastering the cognitive and linguistic tools for modeling the media image of territory.

The study uses many interdisciplinary methods: systemic pragmatic communication method and axiological approach are focused on the use of scientific material in the classroom as a means of effective socialization and interpersonal, as well as mass communication of future specialists.

A survey of active journalists from different communication channels revealed the relevance of the study and the need for pedagogical work aimed at mastering cognitive and linguistic tools for modeling the media image of a territory.

The conceptual modeling method allows us to consider the media image model as an ideal structure that includes the property of its elements (rationality and feelings, cognition and actions) and their cause-and-effect relationships (Erofeeva, 2019). The model's effectiveness is associated with its basic cultural component, the presence of elements of the prototext - the original text that condenses the cultural memory of a person. In this context, we use linguoculturological analysis, which establishes a close relationship between media discourse's cognitive and linguistic tools and the national picture of the author's and the consumer's world.

The list of pedagogical tools includes a systematic and pragmatist communicative method focused on using scientific material as a means of socialization and interpersonal and mass communication of future professionals.

The axiological approach is also relevant in the research context, which is based on an orientation towards the system of social and pedagogical values in the implementation of interactive technologies in the learning process. We also focus on the value of human life, on the approval of the ethical and axiological content of work in the mass media. The practice-oriented approach used is aimed at forming professional competencies in modeling the media image of territory in the space of the media text within the framework of educational activities. The study's relevance and the need for the stated topic are based on a survey of current journalists from various communication channels.

\section{Discussion}

Modern higher education and new standards for training professionals in the field of media are directly focused on forming competencies that allow a specialist to solve a certain class of professional problems. The structure of competencies includes knowledge, abilities, skills, and certain models of behavior. In the information society, competencies associated with the ability to construct a certain image of particular territory are especially in demand. Scientists draw attention to the need for a purposeful and well-thought-out policy of the federal and regional authorities to form a strong brand of territory (Kulibanova, Teor: 129). Accordingly, the technology of modeling the necessary media image is a matter of state priorities. But, unfortunately, from the point of view of stages, structure, and tools of work, this area of activity within the framework of a specific text is poorly represented in the scientific literature. It is practically not worked out in the pedagogy of higher education.

Nevertheless, in working with different textures, the creator of the media text - a journalist or a specialist in advertising and public relations - immanently or deliberately creates an image of territory. Actors of information flows are guided by corporate goals, by factors of interest of the audience, by rating approaches. But the demanded and, accordingly, dominant-negative, aggressive, or entertaining content constructs a destructive image of territory of residence.

In our article, we do not touch upon the general marketing technology of territory branding, which has recently been widely presented in scientific discourse (Dinnie, 2008; 2010; 
Malysheva, Gridnev, 2016; Terskikh, Malenova, 2015; Zakharova, 2020). Scientists consider in detail the methods and mechanisms of branding due to the socio-economic and socio-cultural development of the region (Gridnev, 2016; Lantsevskaya, 2015; Malysheva, Yezhova, 2018, etc.). Beyond the field of our attention in this material, there are theoretical bases of territory branding, technology development strategy of territory brand, brand monitoring methods, and evaluation of its effectiveness.

We are primarily interested in the cognitive and linguistic tools of the media text, which allows us to represent local identity and present it in certain semantic frameworks, as well as in bright and interconnected images that are attractive to the audience.

We take into account the assertion of the researcher Yu. N. Dracheva about the phenomenon of the media image, which functions in mass communication as already existing representations, part of the collective consciousness and "a mental image represented in media texts as a fragment of the information (media) picture of the world." As well as her opinion that "post-mediatextual" media images are "capable of either supporting existing collective representations or changing them in one direction or another using a system of positive or negative assessments, changing the collective representation" (Dracheva, 2019). In mass communication, media images are understood as the reflection of objectively existing reality in the media, the "image of the social world formed by the media" (Lantsevskaya, 2015: 98; Marushchak, 2012), the sum of collective ideas about a fragment of reality," the result of reflecting the "essential characteristics of the state" (Galinskaya, 2013; Gosteva, 2017, Lantsevskaia, 2015).

According to the latest generation standards approved by the Ministry of Education of Russia for the enlarged group of majors 42.00.00., "Mass Media and Librarianship" (the bachelor's and master's degrees, directions "Journalism", "Advertising and Public Relations"), general professional competencies (GPC-2, GPC-5) focus on the ability of students to take into account (or analyze, if it concerns the master student) when making the media content: firstly, the development trends of public and state institutions for their comprehensive coverage, and secondly, the current trends in the development of media communication systems in the region and the country based on the norms of law and ethics, political and economic mechanisms of functioning (Federal State Educationail Standards: https://fgos.ru/).

Lecture and practical courses on the branding of territories work out these competencies in the narrowly focused field of the theory of branding, technologies for its creation, further management, and promotion, emphasizing the importance for the economy and social stability in a region or a country. As a rule, interesting cases of existing global or urban, regional, tourism brands are considered; strategies and stages of territorial branding, possible development, various integrations, and rebranding are systematized.

We propose to include an additional area of creative work of the author of a media text on modeling a competitive and attractive media image of territory using cognitive and linguistic tools.

On the one hand, the problem of branding and image of territories has become relevant in Russia relatively recently; on the other hand, the abundance of scientific materials on this topic should be noted.

The basics of branding, innovative tools for its implementation are presented in the works of foreign (Anholt, 2007; Asplund et al., 2005; Dinny, 2013; Kavaratzis, Hatch, 2013) and domestic authors (Kulibanova, Teor, 2016, 2017).

Often content elements of other types of branding, for example, corporate one, are projected into territorial brand management. According to S. Zenker and E. Brown, the brand of territory is expressed in the peculiarities of communication and design, values and general culture of the region, is a complex of associations in the mind of the consumer, based on "visual, verbal and behavioral manifestations of the characteristics of territory" (Zenker, Braun, 2010: 3). The final goal of territorial branding is to form a generally positive impression of the region as the most preferred place for life in its various manifestations: rest, work, education, housing, medicine, industry, investment and innovation, targeted government programs, etc.

The set of dominant associations and meanings in the information field also creates a certain media image of the territory. The media image is interpreted as "an impression made up of the totality of references to the features and events of such territory" (Lantsevskaya, 2015: 102). This category is presented in various ways in the scientific discourse. On the one hand, the media image is interpreted as a set of emotional and rational representations based on information received from the media (Maruschak, 2012: 95). On the other hand, a media image is a category of media 
creativity of a specific or collective author of a media text, the result of a special interpretation and assimilation of reality from the point of view of the worldview of the linguistic personality of the creator of the text. One cannot but take into account the fact that the media image is built into the two-sided process of its creation in the space of the text by the communicator and the perception of this text by the consumer. The construction of a media text can be spontaneous and chaotic (Galinskaya, 2013: 91), but it is also possible to purposefully model it in the right way, with emphasis on the necessary meanings that originate in the symbolic realities of culture, which will be the subject of our analysis.

In science, the internal image, which absorbs ideas about oneself and the place of direct residence, and the external image, which is created outside the region and reflects the thoughts of others about us, are considered (Kovach, 2019).

The resources of the media image are analyzed by scientists using a different categorical base. So, philologists pay attention to linguistic, connotative, and expressive-evaluative means of verbalizing a media image (Galinskaya, 2015; Erofeeva, 2016; Skidan, 2019; Toropova, 2017). Political scientists formulate the social and ideological tasks of the media image (Shevtsova, 2015; Shmeleva, Kaminchenko, 2019).

The image of territory, recorded in the media, launches the mechanism of social identification that is extremely necessary for a person. That person begins to feel his or her belonging to certain geography of residence. His or her urgent social need for a collective value related to the place of life is implemented. The territory's image is a kind of axiological model of social consciousness; it is the accessible concepts and judgments of members of society about the national and state community (Semenenko, 2008: 6). The parameters of the territory's identity include the attributes of uniqueness, loyalty to the place, cohesion of residents, the ideological and practical potential of identity.

In the situation of an acute geopolitical information war between Russia and the West, the topic of mass identity, woven from symbolic and semantic content and reflecting the specific cultural characteristics of society, becomes especially relevant (Klaudou, 2016; Yanglyaeva, 2019; Zimmerbauer 2008). The process of saturating the media image with fragments of the national picture of the world is not only a strategic task and a way of protection from outside influences but also an opportunity to preserve one's identity, "a special timbre in the symphonic orchestra of mankind" (Gachev, 1997).

Within the framework of current research in cognitive linguistics (Tipton, 2019, WolffMichael, 2013), the linguistic personality of the author of a media product is the bearer of culturallinguistic and communicative-pragmatist values characteristic of a particular society, respectively the author in the process of constructing a media text represents the primordial worldview models through a set of cognitive means. Perceiving and processing the texture, the linguistic personality appeals not so much to the individual irrationality as to the values of the culture in which the person was born and raised. Moreover, the accentuation of the primordial sociocode guarantees the target audience's effective and congruent perception of the text - the bearer of an identical picture of the world. It is no coincidence that Y. Borev designates the interpreter of the text as "a kind of cultural media" (Borev, 2019: 347-348).

In our teaching activities, we rely on these scientific facts. Training of future professionals in the field of mass media, aimed at using cognitive and linguistic means of modeling a media image, is a rather complex and multi-vector task, including not only the theory of cognitive linguistics and psychology of mass media but also a practice-oriented cycle for mastering specific media text technologies. A complex front of work is possible only when using active teaching methods when a student is not only a listener and analyst but an active participant in the process of constructing a media text. Activity learning implies not so much understanding and assimilation of principles and approaches as applying knowledge in practice. This topic becomes the subject of consideration in the studies of I.V. Shumov, I.V. Anashkin, E.V. Zarukin, N.A. Loginov, M.M. Novik, etc.

Researcher E.V. Zarukina refers to active teaching methods as methods with a high degree of involvement of students in the educational process, which makes it possible to awaken cognitive and creative activity in solving the assigned tasks. The features of active teaching methods are purposeful activation of thinking, independent creative development of solutions, an increased degree of motivation and emotionality of trainees, constant interaction of subjects of educational activity, free exchange of views on ways to solve problems (Zarukina et al., 2010). 
The typology of active teaching methods is diverse. So, O. V. Gorshkova differentiates group discussions, business and role-playing games, techniques of brainstorming the case situations, etc. The era of development of Internet technologies has significantly expanded the list of active teaching methods (Gorshkova, 2017). In the educational process, especially in the era of a pandemic, teachers and students often use social networks and instant messengers, webinars, network Internet projects, skype conferences, etc.

\section{Results}

Working with the primordial value tools in constructing the media image of territory is of great state importance since it allows you to reproduce, preserve and broadcast the cultural memory of society. "Acquisition/Resurrection of Sense" (Oleshko, 2019) creates a cultural landscape of a media text in a literal and figurative sense. Nevertheless, this questioning is poorly understood by practitioners, in particular by journalists.

In June 2021, we conducted a survey among representatives of the mass media of the Zabaykalsky Krai on the topic of "Formation of the media image of territory and the work of a journalist", consisting of 11 diverse questions. The study involved 48 workers from different media. Undoubtedly, most of the journalists are worried about the problems of their region. Half of the respondents believe that a journalist in the process of publishing his/her materials should take care of the created image/look of the region or country. But in reality, $53.2 \%$ of authors creating a text do not think about the media image but make topical materials to improve real life in the region or country. At the same time, $50.8 \%$ of the respondents believe that constructing a media image is not a media problem but an exclusively political task. Almost $24 \%$ of respondents are sure that public relations specialists should form the media image of territory. The answers were quite widespread: "This is a problem of the state. The media are just a mirror of reality. There is nothing to blame for it". "This is a complex problem; there is no normal dialogue between the authorities and the media in the region. It harms the media image." At the same time, 40 people $(83.3 \%)$ out of 48 respondents agree that the media image of territory spontaneously or deliberately formed by journalists affects the views, moods, actions of the audience concerning the region or their country.

$74.5 \%$ of respondents believe that the objectivity of the reflection of reality depends on the policy of the mass media, or on the form of ownership of the media. At the same time, almost half of the respondents rarely but embellish or sharply negatively interpret the events/facts with which they work. They do this for the rating or to influence the audience's opinion (42.9\% of the survey participants answered this way).

Journalists strive to initiate the information agenda as an integral part of a person's daily life and choose facts and events for the coverage of the audience's interests. Content that is in demand by the viewer/reader directly affects the attraction of advertisers. The overwhelming majority of the media exist thanks to the placement of ordered materials, which does not always positively affect the formation of the media image of territory. $87.5 \%$ of the interviewed journalists consider it acceptable for themselves to make custom-made materials. At the same time, $39.6 \%$ of the respondents always make promoted stories, explaining that "this is how the media survives." Half of the respondents make promoted stories only when they share the work giver's opinion.

Obviously, in contradiction to all of the above, almost half of the respondents do not agree that the media form a different reality. Few people admit that a journalist's own picture of the world influences news stories' choice and the interpretation of facts and events in the media space.

The survey showed that most journalists have no idea about the media image's meaning, role, and essence. So, they oppose the process of constructing a media image to criticism in their materials, not realizing that a negative assessment of what is happening is also an integral component of the formation of the territory's image. It should be admitted that journalists underestimate their role in creating the media image of the region. However, despite the criticality concerning many of the questions asked, professional intuition and self-preservation instinct forced almost $52 \%$ of journalists to note that the percentage of positive messages in the media should be more than twice as many as negative ones: 70 to 30 .

Positive content typically draws on the spiritual inventory of the primordial worldview. The urgent need to work in this direction within the framework of professional training of students is obvious.

The linguistic personality of the author of the media text uses various methods of conveying culturally significant information. In our scientific research, we designate them as markers of 
Russian culture, enshrined in the conceptual discourse of the media, which indicate (mark) the key features, attitudes, and semes of Russian culture (Erofeeva, 2019). Cognitive markers demonstrate the primary meanings and prototypes of culture and reveal the specifics of typical collective experiences. These include concepts, archetypes, and stereotypes embedded in the narrative context of the mass media. These tools demonstrate the totality of meanings and the entire amount of ideas about the important category of being. Using them, information that is enshrined in the national culture is processed, stored, and transmitted. Concepts are "units of collective knowledge/consciousness" (Vorkachev, 2003) is a semantic and value-based algorithm for processing information that is important for a person in a certain way. Stereotypes are embedded in the conceptual sphere as well-established and ordered images. Archetypes, being innate typical forms of intuition (Jung, 1997: 333), underlie conceptual representations, form the "sediment of the mental experience of all previous generations."

In ordinary creativity, there is a spontaneous representation of the cognitive structures of a linguistic personality. We draw attention to the need for the author to consciously work with these tools in constructing a media text and modeling the image of territory. The indicated direction of creative activity and the corresponding competencies are presented within the framework of the courses "Psychology of Mass Communication", "Branding of the Territory", "Psychological Culture of a Journalist", "Psychology of Media Text".

The proposed technologies of the educational process include a single conceptual part revealing the key meanings and values of the national culture of Russia. The content of the technologies is focused on specific learning goals and the content of a particular educational material. The procedural part demonstrates the arrangement of the educational process, the stages, and the content of the methods of transferring culturally significant information in the media text.

Preference is given to practical active methods based on the activation and intensification of students' activities, which contribute to students' interest in classes, better memorization of the material, and modeling a real classroom situation. In our pedagogical practice, we tend to a problem-based learning framework, when the formulation of the current contradictions of modern mass media pushes students to active independent work to resolve problems, it results in a caring and creative development of professional knowledge and skills, in the crystallization of the value base necessary for successful work.

The teacher's actions in the use of various pedagogical technologies aim to create a favorable atmosphere for the implementation of creative thinking, emphasizing goodwill, mutual understanding, and support. Students should gain experience in using cognitive and linguistic means in a media text and get a positive attitude towards productive communication with others, the ability to hear and perceive a different point of view. All tasks are analytical; students should willingly express their position, think critically, and discuss while solving complex problems and cases. Only in this context, the personal reflection is possible with the value picture of the world of the linguistic personality of the author; only empathy and assistance can awaken the conscious level of work of each student with cognitive and linguistic means of image modeling in the process of his or her creative activity.

So, several lessons on working with concepts include a theoretical part that reveals the categorical basis of the issue: conceptology, mentality, and mindset, concept, conceptual framework, conceptum, meaningful forms of the concept: image, notion, symbol. Further, students are invited to give the opportunity to characterize the existential and cultural constants of Russia: truth/truth; home/family; collegiality; freedom/will; success/fame, etc. The process of classroom and independent work with these established mental representations of Russia is focused on students discovering the correlation of primordial meanings and their transformation in the mass media discourse. Bachelors formulate their vision of media representations of selected concepts in the information field of a region or a country. Undergraduates are invited to carry out an additional linguoculturological analysis of the region's media text, to identify based on content analysis the levels of the primordial representation of the concept and its transformation redesigning with the indication of the reasons and consequences for the psyche and value picture of the world of the target audience. redesigning with the indication of the reasons and consequences for the psyche and value picture of the world of the target audience.

Within the framework of a round table, the teacher initiates a discussion of the documentary films Crimea. The Way Home by A. Kondrashov and Beslan by A. Rogatkin. Through spontaneous and leading questions (What can you say about the film; What the journalist wanted to say in this 
film and through the use of what; what historical or cultural factors influenced the content of the film; which episode do you remember and why), the conversation is brought to the formulation of conceptual ideas of the film content, the nuclear concepts of Russian culture, which are significant for our audience and make the film attractive and convincing for the consumer, are singled out. An important part of the conversation is the concept of patriotism, the highlighting of frames and script markers that form a special attitude towards the country.

Using the methodology of A.V. Fedorov on "the hermeneutic analysis of the cultural context allowing to compare cultural tradition and reality" (Fedorov, 2008), seminars are held on effective technologies of influence in media texts of the Great Patriotic War, special attention is paid to writers and poets working as journalists: M. Sholokhov, I. Erenburg, V. Vishnevsky, A. Tolstoy, etc. The texts are analyzed in a multi-vector manner: 1) cultural and historical factors influencing the author's point of view; 2) cognitive and linguistic means of forming values and cultural relations; 3) the role of the media text in the construction of a positive attitude towards the native land and country.

Separate seminars are devoted to the topic "Information and Psychological Warfare". Partly the classroom involves the methods of L. Masterman and U. Eco which are based on the idea of conditionality of media products (founder, power, authorial ideology). Media texts reflecting regional corporate wars, political information attacks, geopolitical cognitive wars are analyzed according to the following scheme: 1) who owns this media and who controls it; 2) how the effectiveness of the media text is achieved, what cognitive and linguistic means are used; 3) evaluate the responsibility of the author for biased information; 4) what values are formed by the text; 5) characterize the negative impact of the text on the audience's picture of the world; 6) how the text affects the media image of territory.

The package of practical exercises is devoted to cases of urban or national identity. Students are invited to form a "conceptual dossier" for a city, region, or country, using concepts of nature or natural phenomena that are significant for the territory (river, lake, waterfall, mountains, meadows, fish, flowers, white nights, northern lights, etc.), gastronomic concepts (food and nutrition); economic concepts (money, business, property); labor concepts; art concept.

In-game designing is used to master the theory and technology of the archetype. This flexible model of the organization of the educational process is distinguished by a high degree of combination of individual and joint work of students with the simultaneous use of a specific practical task of real journalism to create a ratings-boosting media text.

It is known that archetypes are sacred images of mentality. They are quite attractive to the audience, as they enhance subconscious impressions, can "stir up forgotten memories" (K.G. Jung). The uniqueness of the prototype lies in its ability to broadcast a volumetric layer of demanded meanings with minimal detection. Competent introduction of the archetype into the text sums up the psychic energy of the creator and the consumer, guarantees the effectiveness of the sale of the media product. In the educational process, work with archetypes takes place in three stages: 1) mastering the theory of the issue: history, essence, typology, functions of archetypes; 2) analysis of media content of different communication channels (print, TV, radio, Internet journalism), which uses archetypes. At this stage, students are in search of a familiar archetypal context, analyze not only the means of objectifying the archetype, but also the effect of trust in it from the audience; 3) construction of a media text using an archetype that is significant for a certain territory.

The course is divided into several creative groups according to sympathy for a particular communication channel and work experience in this area. Task: to create a media text using an archetype that is culturally significant for the region. Students are offered a scheme for constructing a media text:

1) determine the genre of the text;

2) formulate the concept of the text using a specific archetype;

3) determine the topic and idea of the text ("text transparency principle");

4) highlight feelings, moods, associations (emotional background) of the text.

5) collect and group facts, arguments, details ("the principle of completeness and adequacy of the introduction of the archetype");

6) designate the archetypal series "the principle of unity and consistency");

7) think over the structure and style of the text ("the principle of observing the aesthetic background"). 
To fix the archetype, operator techniques are used, for example, slow-motion shooting of an object or smooth transitions from general plans to details. The beginning of the work takes place in the classroom. The creative activity on creating the text is continued in the educational television studio, radio studio, and electronic newsroom. A group analysis of the effectiveness of the created materials is carried out at the next practical lesson at the following levels of the text: cognitive (ideological and value level, compliance with the assigned tasks); emotional (attractiveness of the text for the target audience); behavioral (the effectiveness of the impact of the text, the possibility of changing the audience behavior model based on the value paradigm of the text).

Creative individual tasks are also devoted to the formation of competencies for the introduction of an archetype into a media text: create a cloud of archetypal associations for regions of Russia or foreign countries; using an archetypal series or a specific archetype, propose a territory rebranding scheme (optional); create a communication strategy to promote a tourist destination in the province; visualize the brand of the city and region; think over the color scheme of the city's electronic portal.

After mastering the conceptual framework and archetypes material, students are offered tasks of a complex narrative nature. 1) Using storytelling technologies and real regional or allRussian texture, build stories that actualize the nuclear semes of culture (the scenario of "Fall and Rise"; mythologeme of the Path as a universal symbol of fate and self-realization in a situation of difficult life choices; scenario marker "East-West", in within which the originality of the territory is realized primarily through the antithesis of the West and the East). 2) Create essay materials for different target audiences, focused on the search for urban/regional identity.

\section{Conclusion}

The cognitive tools combine verbal and non-verbal components; they address different levels of human perception and successfully synthesize semiotic systems and cultural codes; they are designed to accumulate motives and awaken the desires of the reader, listener, viewer; they can provoke their certain behavioral strategies.

The main media educational result of the lesson is the formation of a system of necessary competencies for future professionals. Indicators of achieving competencies in the use of cognitive and linguistic resources when modeling the image of territory in a media text (according to the "Know-Can-Own" model) include:

- formation of knowledge of the main features and stages of development of territorial branding; key attributes of territory identification; the main cognitive and linguistic tools for promoting the territory: the theory and ways of representing concepts, stereotypes, archetypes;

- acquisition of skills to freely navigate in different technologies and areas of territory branding; to form the perception of the territory through the active use of cognitive and linguistic means;

- mastering the skills of creating an attractive image in the media text by attracting cognitive structures that actualize society's cultural memory; the skills of forming a positive perception of the image of territory in the media text space; skills in implementing projects in the field of territory brand modeling.

A set of teaching methods of multifaceted nature, combining theoretical and practical mastering of reality, allows you to implement the goals set in the educational process. The priority is given to the culturological model of education, which emphasizes the need to fill the educational environment not only with personal and professional but also with socio-cultural meanings characteristic of territory of a person's residence.

Undoubtedly, the media image of a country is a complex and ambiguous gestalt of mass media, accumulating impressions and knowledge, as well as a possible strategy of action concerning a certain territory. The internal and external media image created or perceived reflects the linguistic consciousness of the subject included in this process. Modeling the media image of a country is a complex work of a linguistic personality with the active use of cognitive tools: concepts, stereotypes, archetypes, scenario markers (narrative). The tool used demonstrates the cultural landscape of the media text. The productive media image of the country includes a set of key values of the life of people of certain territories in the "past-present-future" paradigm.

The applied primordial cognitive toolkit simulates the cultural landscape of a media text, which in turn translates a productive media image of a country, including a set of key values of the life of people of the certain territory in the "past-present-future" paradigm. 
A person, as a rule, appeals with mental constructions in the process of perceiving and reflecting information. The dominant media discourse can become a platform for translating cultural meanings and a semiotic space of genetic knowledge. This allows the creation of rating content and provides the national identity necessary for any society.

\section{Acknowledgments}

The research was carried out within the framework of RFBR grant: project № 19-013-00725 "Media image of Russia in the context of national security".

\section{References}

Anholt, 2007 - Anholt, S. (2007). Competitive The New Brend Management for Nations, Cities and Regions. Palgrave, Macmilan.

Balalueva, 2014 - Blalueva, I.A. (2014). Media-imidzh i sotsial'nyy imidzh: protsessy vzaimnogo upravleniya $\mathrm{v}$ informatsionnom obshchestve [Media image and social image: processes of mutual management in the information society]. Moscow. [in Russian]

Borev, 2002 - Borev, Yu.B. (2002). Estetika [Aesthetics]. Moscow. [in Russian]

Chuvakova, Sbusina, 2011 - Chuvakova S.G., Sbusina M.V. (2011). Obraz regiona, teoreticheskiye podkhody i yego klassifikatsiya: regional'naya ekonomika: teoriya i praktika [Image of the region, theoretical approaches and its classification]. Regional'naya ekonomika: teoriya $i$ praktika - Regional economy: theory and practice. 3.17(200): 43-47. [in Russian]

Dinnie, 2008 - Dinnie K. (2008). Nation Branding - Concepts, Issue and Practic. Butterworth-Heinemann Elsevier Linacre. House. [Electronic resource]. URL: https://docviewer. yandex.ru/view/11290312/?page $=4 \&$

Dinnie, 2013 - Dinny, K. (2013). Territory branding. The world's best practices. Moscow: Mann, Ivanov and Ferber. $336 \mathrm{p}$.

Dracheva, 2019 - Dracheva, I.N. (2019). Ponyatiye media-imidzha i yego izucheniye v lingvisticheskom i nelingvisticheskom aspektakh [The notion of media image and its study in linguistic and nonlinguistic aspects]. Vestnik Cherepovetskogo gosudarstvennogo universiteta. 2(89): 134-146. DOI: 10.23859/1994-0637-2019-2-89-13 [in Russian]

Erofeeva, 2019 - Erofeeva, I.V. (2019). Lingvokul'turologicheskoye modelirovaniye mediateksta kak instrument natsional'noy bezopasnosti [Linguoculturological modeling of media text as an instrument of national security]. Media $v$ sovremennom mire. Peterburgskie chteniya: Materialy 58-go Mezhdunarodnogo. St. Petersburg. 2: 47-49. [in Russian]

Evseev, 2020 - Evseev, A.Yu. (2020). Strategicheskiye kommunikatsii v realizatsii mediapolitiki Chechenskoy Respubliki [Strategic communications in the implementation of the media policy of the Chechen Republic]. Vestnik Voronezhskogo gosudarstvennogo universiteta. Seriya Filologiya. Zhurnalistika. 2: 94-97. [in Russian]

Fedorov, 2008 - Fedorov, A.V. (2008). Germenevticheskiy analiz kul'turnogo konteksta protsessov funktsionirovaniya media $\mathrm{v}$ obshchestve i mediatekstov na urokakh $\mathrm{v}$ studencheskoy auditorii [Hermeneutic analysis of the cultural context of the processes of functioning of media in society and media texts in the classroom in the student audience]. Innovatsii v obrazovanii. 8: 99-126.

Galinskaya, 2013 - Galinskaya, T.N. (2013). Ponyatiye media-obraza i problema yego rekonstruktsii v sovremennoy lingvistike [The concept of a media image and the problem of its reconstruction in modern linguistics]. Vestnik Orenburgskogo gosudarstvennogo universiteta. 160(11): 91-94. [in Russian]

Gorbal, 2020 - Gorbal, D.E. (2020). Sovremennyye podkhody k fenomenu media-imidzha [Modern approaches to the phenomenon of the media image]. Nauka $i$ obrazovanie. 71-75. [in Russian]

Gorshkova, 2017 - Gorshkova, O.V. (2017). Aktivnyye metody obucheniya: formy i tseli primeneniya [Active teaching methods: forms and purposes of application]. Concept. 53 . [Electronic resource]. URL: http://www.e-koncept.ru/2017/470039.htm [in Russian]

Gosteva, 2017 - Gosteva, D.D. (2017). Problema postroyeniya obraza sotsial'nogo mira v informatsionnuyu epokhu: kommunikativnyy aspect [The problem of constructing the image of the social world in the information age: the communicative aspect]. Vestnik Vyatskogo gosudarstvennogo universiteta. 9: 17-22. 
Gromova, 2019 - Gromova, S. (2019). Struktura mediaimidzha Rossii: vneshnepoliticheskiy aspect [The structure of the media image of Russia: foreign policy aspec]. Znak: problemnoye pole mediaobrazovaniya. 4: 62-67. [in Russian]

Kavaratzis, Hatch, 2013 - Kavaratzis, M., Hatch, M. J. (2013). Dinamika brendov mest: podkhod na osnove identichnosti $\mathrm{k}$ teorii brendinga mest [The Dynamics of Place Brands: An identity Based Approach to Place]. Teoriya brendinga. Teoriya marketinga. 13(1): 1-18. St. Petersburg. [in Russian]

Khochunskaia, 2011 - Khochunskaia, L.V. (2011). Media-imidzh kak dialog tsennostey [Media image as a dialogue of values]. Moscow. [in Russian]

Klaudou, 2016 - Klaudou, S. (2016). Rol' elementov brenda v brendinge destinatsii [The role of brand elements in destination branding].Zhurnal Destination Marketing @ Management.6(4): 426-435.

Kolesov, 2019 - Kolesov, V.V. (2019). Osnovy kontseptologii [Fundamentals of conceptology]. St. Petersburg. [in Russian]

Kotler et al., 2005 - Kotler, F., Aspund, P., Rein, Haider D. (2005). Place marketing. Attracting investments, enterprises of residents and tourists to cities, communes, regions and countries of Europe. Moscow.

Kovach, 2019 - Kovach, O.A. (2019). Printsipy postroyeniya media-imidzha gosudarstva [Principles of constructing a media image of the state]. Media-sreda. 15: 57-62.

Kulibanova, Teor, 2017 - Kulibanova V.V., Teor, T.R. (2017). Innovatsionnyye kanaly prodvizheniya brenda territorii [Innovative channels for promoting the brand of the territory]. Nauchnye tekhnologii SPbGPU. Nauchno-tekhnicheskii vestnik SPbGPU. Ekonomicheskie nauki. 10(6): 162-171. [in Russian]

Lantsevskaia, 2015 - Lantsevskaia, N.Iu. (2015). Media-imidzh territorii kak sovokupnost' stereotipov brendinga prostranstva [The territory's media image as a set of stereotypes branding space]. Vestnik Shadrinskogo gosudarstvennogo pedagogicheskogo instituta. 4: 101-103. [in Russian]

Malysheva, Gridnev, 2016 - Malysheva, E.G., Gridnev, N.A. (2016). Postroyeniye mediynogo imidzha regiona $\mathrm{v}$ federal'nykh telekanalakh (na primere tekstov ob Omske) [Constructing a media image of region in federal television media (by example of texts about Omsk)]. Nauchnyy dialog. 12(60): 134-144. [in Russian]

Markina, 2020 - Markina, Yu.M. (2020). Kommunikatsionnaya strategiya brenda territorii: potentsial i riski [Communication strategy of the territory brand: potential and risks]. Brending kak kommunikatsionnaya tekhnologiya XXI veka. Ch. Proceedings of the VI International Conference on February 27-28 and April 23-24, 2020. St. Petersburg: 216-2019. [in Russian]

Marushchak, 2012 - Marushchak, A.V. (2012). Politicheskiy i sotsial'nyy obraz Rossii v amerikanskom mediaprostranstve [The political and social image of Russia in the American media space]. Zhurnalistskii ezhegodnik. 1: 93-96. [in Russian]

Nuortimoa et al., 2018 - Nuortimoa, K., Härkönenb J., Karvonenc E. (2018). Exploring the global media image of solar power. Renewable and Sustainable Energy Reviews. 81: 2806-2811. DOI: 10.1016/j.rser.2017.06.086

Oleshko, 2019 - Oleshko, V.F., Oleshko, E.V. (2019). Kommunikativnaya i kul'turnaya pamyat': identifikatsionnyye resursy sovremennykh SMI [Communicative and cultural memory: identification resources of modern mass media]. Gumanitarnyi vector. 14(5): 77-86. [in Russian]

Parkhomenko, 2015 - Parkhomenko, Ia.A. (2015). Publitsisticheskaya sostavlyayushchaya imidzha SMI [The publicistic component of the media image]. Vetnik elektronnykh $i$ pechatnykh SMI. (23): 31-49. [in Russian]

Semenenko, 2008 - Semenenko, I.S. (2018). Obrazy i imidgi v diskurse natsional'noy identichnosti [Images and images in discourse national identity]. Polis. Politologiya. 5: 7-18. [in Russian]

Shevtsova, 2015 - Shevtsova, D.A. (2015). Ot publitsisticheskogo obraza k media-imidzhu: razvitiye nauchnoy mysli [From the publicistic image to the media image: the progression of scientific thought]. Sovremennye problemy nauki i obrazovaniya. 2-3: 73. [in Russian]

Shmeleva, 2017 - Shmeleva, O.Yu. (2017). Imidzh gosudarstva kak kategorii politicheskoy nauki: teoretiko-metodologicheskiye aspekty issledovaniya [Image of the State as a Category of Political Science: Theoretical and Methodological Aspects of Study]. Politicheskaya ekspertiza: Politeks. 4: 23-36. [in Russian] 
Shmeleva, Kaminchenko, 2019 - Shmeleva, O.Yu., Kaminchenko, D.I. (2019). Sotsial'nyye seti kak mekhanizm formirovaniya imidzha sovremennogo gosudarstva v politicheskom soznanii rossiyan [Social media as a mechanism for the formation of the image of a modern state in the political consciousness of Russians]. Vestnik Moskovskogo gosudarstvennogo oblastnogo universiteta. 3: 87-10. [in Russian]

Skidan, 2019 - Skidan, O.G. (2019). Formirovaniye mediynogo obraza v pechatnykh SMI: lingvokognitivnyy aspect [Formation of a media image in print media: linguo-cognitive aspect]. Gumanitarnye chteniya “Sevastopol'skaya gavan'”. 29-34. [in Russian]

Smeleva, 2017 - Shmeleva, O. (2017). Imidzh gosudarstva kak kategorii politicheskoy nauki: teoretiko-metodologicheskiye aspekty issledovaniya [Image of the State as a Category of Political Science: Theoretical and Methodological Aspects of Study]. Political Expertise: Politex. 4: 23-36.

Terskikh, Malenova, 2015 - Terskikh, M.V., Malenova, E.D. (2015). Media-imidzh Sibirskogo regiona: lingvokognitivnoye modelirovaniye [Media image of the Siberian region: linguo-cognitive modeling]. Omsk. [in Russian]

Tipton, 2009 - Tipton, F.B. (2009). Modeling national identities and cultural change: The Western European, Japanese, and United States Experiences Compared. International Journal of Cross Cultural Management. 9(2): 145-168.

Toropova, 2017 - Toropova, S.A. (2017). Media-imidzh Kitaya v rossiyskom informatsionnom pole: osnovnyye sostavlyayushchiye [Media image of China in the Russian information field: main components]. Science today: problems and development prospects. Nauka segodnya: problemy i perspektivy razvitiya. Materials of the international scientific and practical conference: in 3 parts: 140-142. [in Russian]

Vorkachev, 2003 - Vorkachev, S.G. (2003). Kul'turnoye ponyatiye i znacheniye. [Cultural concept and meaning]. Trudy Kubanskogo gosudarstvennogo tekhnologicheskogo universiteta. Ser. Humanitarian sciences. 17(2): 268-276.

Wolff-Michael $2013-$ Wolff-Michael $R$. (2013). On Meaning and Mental Representation. Springe.

Yezhova, Maslyuk, 2018 - Yezhova, E.N., Maslyuk, D.S. (2018). Dominanty imidzha Severnogo Kavkaza v rossiyskom segmente sotsial'nykh setey [Dominants of the image of the North Caucasus in the Russian segment of social networks]. Strategic communications in business and politics: mater. international scientific. conf. (November 22-23, 2018). Le Havre. St. Petersburg. 4: 334. [in Russian]

Yezhova, Maslyuk, 2018 - Yezhova, E.N., Maslyuk, D.S. (2018). Dominanty imidzha Severnogo Kavkaza v rossiyskom segmente sotsial'nykh setey [Dominants of the image of the North Caucasus in the Russian segment of social networks]. Strategicheskie kommunikatsii $v$ biznese $i$ politike: mater. international scientific. conf. (November 22-23, 2018). Le Havre. St. Petersburg. 4: 334-336. [in Russian]

Zakharova, 2020 - Zakharova, A. (2020). Prodvizheniye brendinga goroda: zarubezhnyy opyt - Promotion of city branding: foreign experience. Brending kak kommunikativnaya tekhnologiya. 2020. Proceedings of the VI international conference. St. Petersburg: 136-138. [in Russian]

Zarukina et al., 2010 - Zarukina, E.V., Loginova, N.A., Novik, M.M. (2010). Aktivnyye metody obucheniya: rekomendatsii po primeneniyu [Active teaching methods: recommendations for use]. Ekaterinburg. [in Russian] 